\title{
Digital natives on a media fast ${ }^{1}$
}

\author{
David Silver \\ University of San Francisco, San Francisco, CA, USA \\ E-mail:dmsilver@usfca.edu
}

In fall 2011, I taught two sections (forty students each) of Introduction to Media Studies, a brief, fifteen-week overview of mostly Western and US media history. We began with the printing press, marched through newspapers, magazines and the book industry, and sailed through radio, film and television. We spent the last third of the course with "everything else" - the personal computer, email, the information superhighway, the internet, the Web, Web 2.0, computer games, Facebook, Twitter, smart phones, apps and i-everythings - essentially, anything digital, networked, and, increasingly, mobile.

Towards the end of the semester, I gave my students a fairly straight-forward homework assignment. It was a media fast.

Media fast homework assignment:

(1) Sometime between Thursday, October 27 and Monday, October 31, stop using all modern media. You can read books and magazines and papers, but stop using media that is electronic or digital. No iPhones, no Facebook, no text. No computers, TVs or radios. Mark the time your media fast begins.

(2) Continue your fast for as long as possible - the longer, the better.

(3) When your absence from media becomes dangerous, impossible or unbearable, return to them. Note which device you broke your fast with and record the time.

(4) Calculate how long your media fast lasted.

(5) Take some time - a few hours, a day - to reflect upon what happened.

(6) In no more than one page, share your findings. Make sure your name is on the page and bring it to class on Tuesday, November 1.

The students' reflections were staggering. With a few notable exceptions, their all-the-time and everywhere dependence on and desire for media was distressing, depressing and dangerous.

I decided to give them a second media fast - this time as a take-home final. The assignment was essentially the same as the first media fast except students were required to select a brief portion of their reflection and cut-and-paste it as a comment to the online assignment hosted on my blog, silver in sf. (To see the assignment and over seventy student comments, visit: http://bit.ly/mediafast2)

Although I cannot fit a full discussion of the students' reflections into this brief position paper, I do want to spotlight a few key facts and findings.

The shortest media fast was for "about an hour". The longest was three and a half days.

\footnotetext{
${ }^{1}$ This work is licensed under the Creative Commons Attribution-Noncommercial No Derivations Works 3.0 Unported license. You are free to Share this work (copy, Distribute and transmit) under the following conditions: attribution, noncommercial and no derivative works. To view a copy of this license, visit http://creativecommons.org/licenses/by-nc-sa/3.0/.
} 
Multiple students reported having long conversations with their friends, family members or roommates. One student, AC, wrote: "I told my roommate about this assignment and she wanted to try the fast with me. So around 6:30 we closed our laptops, put down our phones and turned off our room iPod stereo system.... At first it was a little awkward being so quiet in the room but after a little bit, my roommate and I had a really nice roommate talk where we talked about our day and our problems. It really made us feel like we knew each other much better and it was kind of nice not having something distracting me on the other side of my mind". Another student had her first ever conversation with her roommate, a fellow student with whom she had lived for the last two months.

Many students wrote that the most difficult times were "when strange and funny things happened to me and I had no one to tell!" One student wrote, "I learned something new and wanted to share"; another wrote, "I saw something funky and wanted to share (via Instagram, Facebook or flickr)". Our students are sharers.

Through the media fast, many students witnessed first-hand how pervasive media is in their (and our) everyday lives. One student, SM, wrote: "There was a TV on at the party, my roommate was trying to show me pictures online, my boyfriend was trying to get me to look at a map online, an acquaintance was asking me for help with their phone, and I was surrounded by phones and computers at Starbucks". Many students realized, Matrix-like, that all of their friends, roommates, and acquaintances are always on their phones. "OMG", one student wrote, in caps, "ALL OF MY FRIENDS ARE ALWAYS ON THEIR PHONES. LIKE, ALL OF THE TIME".

And then, of course, many students realized that, well, they were always on their phones. Many students, including DB, described a nervous tick when away from their media, especially their smart phones: "Something that struck me during my fast was a nervous tick I have with checking my cell phone. Any awkward moment, walk up the stairs, wait in line, basically any insignificant moment of inactivity gives me the sudden urge to check my cell phone. This is almost ALWAYS done even though I am aware there is nothing to check on my phone".

Perhaps the most frightening finding, for me at least, was multiple students' expressing their fears of silence. RT wrote: "I began my media fast at 7 PM on Friday night when I was getting ready to get coffee with friends. It was really weird not listening to music during that time, silence creeps me out". And CK wrote: "On Friday night I felt too in my head during this media fast. At the end of the night I was home just laying on my couch. I couldn't turn on a movie or play music. I felt uncomfortable sitting in silence. All I could hear were my thoughts. It was weird to be stuck in my mind and I didn't like it".

As librarians, educators, and information professionals, we need to understand the all-of-my-mediaall-of-the-time ecology our students - and ourselves - live in. In addition to understanding this phenomenon, we must challenge it - which, if this position paper contains a position, I guess that's it.

As discussed briefly during the Information Professionals 2050 symposium and conference - and in more depth as a keynote talk for BayNet 2012 at San Francisco Public Library (video here: http://bit.ly/baynet2012) - I challenge my students (and myself) using two teaching strategies. The first is what I call log off before you blog off - any kind of assignment that require students to have sensesdriven experiences in physical spaces prior to sharing their experiences online. For example, in my Green Media course, an advanced social media production class focused on making media about making food, my students are required to physically visit a local farmer's market and walk around, talk to the farmers, and see, smell, touch, and taste the purchase. The idea is to encourage (by requiring) students to unplug for just a moment or an hour or an afternoon to experience something offline before they jump back online to share their observations. 
The second pedagogical strategy is what I call seasonal syllabi, a collective effort my Urban Ag faculty colleagues Melinda Stone, Justin Valone and Seth Wachtel and I have been working on for the last five years. Here, class readings and activities - the "stuff" of syllabi - are influenced highly by the seasons. If the lesson involves planting a crop or harvesting a bed or cooking up a meal, we begin with an obvious question: What's in season? While we certainly wish to heighten our students' awareness and appreciation of the seasons, another goal is to engage our students' attention spans beyond "about an hour", beyond a single lecture or class discussion, beyond a class. We want our students' attention span to be - at least - a season. 